\title{
Leptin receptors in human skeletal muscle
}

\author{
Borja Guerra, ${ }^{1}$ Alfredo Santana, ${ }^{2}$ Teresa Fuentes, ${ }^{1}$ Safira Delgado-Guerra, ${ }^{1}$ \\ Alfredo Cabrera-Socorro, ${ }^{3}$ Cecilia Dorado, ${ }^{1}$ and Jose A. L. Calbet ${ }^{1}$ \\ ${ }^{1}$ Department of Physical Education, University of Las Palmas de Gran Canaria, Las Palmas de Gran Canaria, \\ ${ }^{2}$ Genetic Unit, Childhood Hospital Materno Infantil de Las Palmas, Las Palmas de Gran Canaria, and \\ ${ }^{3}$ Department of Anatomy, Faculty of Medicine, University of La Laguna, La Laguna, Canary Island, Spain
}

Submitted 20 November 2006; accepted in final form 10 January 2007

\begin{abstract}
Guerra B, Santana A, Fuentes T, Delgado-Guerra S, CabreraSocorro A, Dorado C, Calbet JA. Leptin receptors in human skeletal muscle. J Appl Physiol 102: 1786-1792, 2007. First published January 18, 2007; doi:10.1152/japplphysiol.01313.2006.-Human skeletal muscle expresses leptin receptor mRNA; however, it remains unknown whether leptin receptors (OB-R) are also expressed at the protein level. Fourteen healthy men $($ age $=33.1 \pm 2.0 \mathrm{yr}$, height $=$ $175.9 \pm 1.7 \mathrm{~cm}$, body mass $=81.2 \pm 3.8 \mathrm{~kg}$, body fat $=22.5 \pm$ $1.9 \%$; means $\pm \mathrm{SE}$ ) participated in this investigation. The expression of OB-R protein was determined in skeletal muscle, subcutaneous adipose tissue, and hypothalamus using a polyclonal rabbit antihuman leptin receptor. Three bands with a molecular mass close to 170,128 , and $98 \mathrm{kDa}$ were identified by Western blot with the anti-OB-R antibody. All three bands were identified in skeletal muscle: the $98-\mathrm{kDa}$ and $170-\mathrm{kDa}$ bands were detected in hypothalamus, and the $98-\mathrm{kDa}$ and $128-\mathrm{kDa}$ bands were detected in thigh subcutaneous adipose tissue. The $128-\mathrm{kDa}$ isoform was not detected in four subjects, whereas in the rest its occurrence was fully explained by the presence of intermuscular adipose tissue, as demonstrated using an anti-perilipin A antibody. No relationship was observed between the basal concentration of leptin in serum and the 170-kDa band density. In conclusion, a long isoform of the leptin receptor with a molecular mass close to $170 \mathrm{kDa}$ is expressed at the protein level in human skeletal muscle. The amount of $170-\mathrm{kDa}$ protein appears to be independent of the basal concentration of leptin in serum.
\end{abstract}

obesity; adipose tissue; hypothalamus; perilipin

LEPTIN IS A 16-KDA HORMONE structurally related to cytokines (66) that plays a crucial role in the regulation of appetite and fat deposition $(20,38)$. This hormone is primarily released by white adipose tissue and acts on brain and peripheral receptors $(19,24,45)$ that belong to the class I type cytokine receptor family $(61,65)$. There are at least six isoforms of leptin receptors (OB-Rs) generated by mRNA alternative splicing and/or proteolytic processing of the subsequent protein products $(18,33,61)$. All of these receptors contain identical extracellular and transmembrane domains and differ in the length of the intracellular amino acid sequence $(18,33,61)$. The long form of the leptin receptor (OB-Rb) has an intracellular domain, highly conserved in several species, that is critical for the effects of this hormone $(18,61,65)$. Upon leptin binding, the $\mathrm{OB}-\mathrm{Rb}$ is activated, leading to stimulation of the janus kinase/signal transducer and activator of transcription signaling pathway, like the other class I cytokine receptors (9, $12,61)$. In the central nervous system, leptin/OB-Rb interaction leads to the activation of janus kinase- 2 by transphosphorylation and subsequent phosphorylation of tyrosine res-

Address for reprint requests and other correspondence: B. Guerra, Departamento de Educación Física, Campus Universitario de Tafira, 35017 Las Palmas de Gran Canaria, Canary Island, Spain (e-mail: borja.guerra@gmail.com). idues (Tyr985 and Tyr1138) in the cytoplasmic part of OB-Rb $(11,27)$.

Expression of OB-R mRNA has also been found in nonneuronal tissues (32), such as bone, heart, liver, lung, adrenal glands, testes, spleen, small intestine, pancreatic islets, the placenta, adipose tissue, and skeletal muscle $(1,10,21,36,43$, 48). However, the presence of OB-R protein has not been shown in some human tissues in which mRNA for OB-R has been detected, such as skeletal muscle (17), cultures of primary skeletal muscle cells (55), subcutaneous adipose tissue (51), and hypothalamus (15).

In addition to its locomotive function, skeletal muscle accounts for the majority of the basal metabolic rate and is also the primary tissue responsible for whole body glucose and fatty acid metabolism (57). Animal experiments have shown that leptin has physiological effects in skeletal muscle $(17,23,37)$; however, it remains unknown if human skeletal muscle is actually able to respond to circulating leptin (7). Plasma leptin concentration is directly proportional to adipose tissue mass. Increasing fat mass results in higher levels of circulating leptin $(19,24)$, while reducing the body fat stores through regular exercise and/or dieting results in lower plasma leptin concentrations $(28,46,62)$. Human obesity is characterized by a high concentration of leptin in plasma associated with leptin resistance $(8,60)$. Obesity also causes insulin resistance in humans $(30,44)$, which has been associated with raised plasma leptin concentrations, independent of body fat mass $(50,56)$. Leptin resistance could be caused by a downregulation and/or desensitization of OB-Rs, among other mechanisms.

In this study, we planned to test two hypotheses: first, that leptin receptors are expressed at the protein level in human skeletal muscle; and second, that the amount of OB-R protein expression in skeletal muscles depends on the basal concentration of leptin. To test these hypotheses, we carried out Western blot analysis in protein extracts obtained from human muscle biopsies and from a human hypothalamus. The hypothalamus protein extract was used as a control to verify that any band identified as a potential OB-R in muscle is also present in the hypothalamic protein extract, since the hypothalamus is rich in OB-R protein content (53). To test the second hypothesis, we determined whether plasma leptin concentration correlates with the protein expression of OB-R in skeletal muscle.

\section{MATERIALS AND METHODS}

Materials. The Complete protease inhibitor cocktail was obtained from Roche Diagnostics (Mannheim, Germany). The polyclonal rab-

\footnotetext{
The costs of publication of this article were defrayed in part by the payment of page charges. The article must therefore be hereby marked "advertisement" in accordance with 18 U.S.C. Section 1734 solely to indicate this fact.
} 
bit anti-human leptin receptor that recognizes the extracellular domain of human leptin receptor was obtained from Linco Research (St. Charles, MO). The recombinant human (RH) leptin R/Fc chimera, generated from DNA containing the extracellular domain of OB-R (amino acid residues 1-839) fused to the Fc region of human $\operatorname{IgG}_{1}$, was obtained from R\&D Systems (McKinley Place). The monoclonal mouse anti- $\alpha$-tubulin antibody was obtained from Biosigma (Madrid, Spain). The secondary horseradish peroxidase (HRP)-conjugated goat anti-rabbit and donkey anti-mouse antibodies were from Jackson ImmunoReseach (West Grove, PA). The Hybond-P transfer membranes, Hyperfilm enhanced chemiluminescence (ECL), and the ECL plus Western Blotting Detection System were from Amersham Biosciences (Little Chalfont, Buckinghamshire, UK). The GS-800 Calibrated Densitometer and the image analysis software Quantity One were obtained from Bio-Rad Laboratories (Hemel Hempstead, Hertfordshire, UK).

Subjects. Fourteen healthy men (age $=33.1 \pm 2.0 \mathrm{yr}$, height $=$ $175.9 \pm 1.7 \mathrm{~cm}$, body mass $=81.2 \pm 3.8 \mathrm{~kg}$, body fat $=22.5 \pm$ $1.9 \%)$ participated in this investigation. Written, informed consent was obtained from each subject after they received a full explanation about the study procedures. The study was performed in accordance with the Helsinki Declaration of 1975 and approved by the Ethical Committee of the University of Las Palmas de Gran Canaria.

General procedures. The body composition of each subject was determined by dual-energy X-ray absorptiometry (Hologic QDR1500, Hologic, software version 7.10, Waltham, MA), as described elsewhere $(5,6,52)$. On a different day, following an overnight fast, a muscle biopsy was obtained from the middle portion of the vastus lateralis muscle using Bergstrom's technique without suction, as described elsewhere (35). The muscle specimen was cleaned to remove any visible blood, fat, or connective tissue. Then the muscle tissue was immediately frozen in liquid nitrogen and stored at $-80^{\circ} \mathrm{C}$ for later analysis. In some subjects, a small piece of subcutaneous adipose tissue was also sampled $(2-3 \mathrm{~cm})$ apart from the incision, using the same kind of needle without suction to minimize the risk of contamination of the subcutaneous biopsy with blood.

Human brain material. The OB-R expression was determined in a protein extract from adult human hypothalamus by Western blot analysis. The rationale for targeting this tissue is the high content of OB-R protein found in rodents (49), and expression of OB-R mRNA (both short and long isoforms) has been reported in human hypothalamus (15). The hypothalamic extracts were prepared using unfixed brain obtained from necropsies of three cognitively normal subjects (aged 26-75 yr), whose brains were extracted shortly after death $(<10$ $\mathrm{h}$ postmortem) and frozen at $-80^{\circ} \mathrm{C}$. The donors had no neurodegenerative disease. These procedures conformed with the rules of the Ethical Committee of the University of La Laguna in accordance with the declaration of Helsinki. Material from these brains has also been used in other studies (16).

Protein preparation for Western blotting. For total protein extraction from human skeletal muscle and subcutaneous adipose tissue, a piece of frozen tissue was homogenized in urea lysis buffer [6 M urea, $1 \%(\mathrm{wt} / \mathrm{vol}) \mathrm{SDS}$, and $1 \times$ of Complete protease inhibitor]. For protein extraction from human hypothalamus, a piece of frozen tissue was homogenized in Tween 20 lysis buffer [0.0625 M Tris $\cdot \mathrm{HCl}, \mathrm{pH} 7.4$, $1 \%$ (wt/vol) Tween 20 , and $1 \times$ of Complete protease inhibitor]. After centrifugation at $20,000 \mathrm{~g}$ to remove tissue debris, total protein extracts were transferred to clean tubes, and an aliquot of each extract was preserved for protein quantification by bicinchoninic acid assay (54).

A whole blood protein extract was obtained from $10 \mathrm{ml}$ of EDTA anticoagulated blood that was drawn from an antecubital vein. The blood was mixed with a hypotonic solution, and, after erythrocyte lysis, the pellet, containing the leukocytes, was extracted using the urea lysis buffer and procedures described above.

Electrophoresis and Western blot analysis. Proteins were solubilized in sample buffer containing $0.0625 \mathrm{M}$ Tris $\cdot \mathrm{HCl}, \mathrm{pH} 6.8,2.3 \%$ (wt/vol) SDS, $10 \%$ (vol/vol) glycerol, $5 \%$ (vol/vol) $\beta$-mercaptoetha- nol, and $0.001 \%$ (wt/vol) bromophenol blue. Equal amounts $(50 \mu \mathrm{g})$ of each sample were electrophoresed on 7.5-10\% SDS-PAGE using the system of Laemmli (31) and transferred to Hybond-P membranes, according to the method of Towbin et al. (63). For immunoblotting, membranes were preincubated with $5 \%$ blotting grade blocker nonfat dry milk (Bio-Rad Laboratories, Hercules, CA) in Tris-buffered saline with $0.1 \%$ Tween 20 (blotto blocking buffer) for $1 \mathrm{~h}$ at room temperature $\left(20-22^{\circ} \mathrm{C}\right)$. To detect the leptin receptor isoforms (OB-Rs), membranes were incubated with a rabbit polyclonal-specific anti-human OB-R antibody. To control for differences in loading and transfer efficiency across membranes, an antibody directed against $\alpha$-tubulin was used to hybridate on the same samples. Membrane incubations with polyclonal rabbit anti-OB-R (diluted 1:2,000 in blotto blocking buffer) were performed overnight at $4{ }^{\circ} \mathrm{C}$. Membrane incubations with monoclonal mouse anti- $\alpha$-tubulin (diluted 1:70,000 in blotto blocking buffer) were performed for $1 \mathrm{~h}$ at room temperature. As control for adipose tissue protein presence in muscular tissue, a polyclonal rabbit anti-perilipin A antibody was used (64). To explore the expression of this protein in human skeletal muscle and subcutaneous adipose tissue, membranes were blocked with 4\% BSA (Sigma, Madrid, Spain) in Tris-buffered saline with $0.1 \%$ Tween 20 (BSA blocking buffer) for $1 \mathrm{~h}$ at room temperature. Membrane incubations with polyclonal rabbit anti-perilipin A antibody (diluted 1:1,500 in BSA blocking buffer) were performed for $1 \mathrm{~h}$ at room temperature. Antibody-specific labeling was revealed by incubation with a HRPconjugated goat anti-rabbit antibody $(1: 20,000)$ or a HRP-conjugated donkey anti-mouse $(1: 10,000)$ antibody, both diluted in blotto blocking buffer and visualized with the ECL kit (Amersham Biosciences). Specific bands were scanned with the GS-800 Calibrated Densitometer and analyzed with the image analysis program Quantity One (Bio-Rad Laboratories, Hercules, CA). Data are reported as band intensity of immunostaining values (arbitrary units) obtained for OB-R relative to those obtained for $\alpha$-tubulin. $\alpha$-Tubulin content in the muscle biopsies was similar in all of the subjects analyzed (3.54 \pm 0.22 arbitrary units of band density of immunostaining).

Competitive assays for $O B-R$. To evaluate the specificity of the anti-OB-R antibody used in this investigation, competitive assays were performed with increasing amounts of RH leptin R/Fc (RH OB-R) chimera $(0,10,100,500 \mathrm{ng})$ preincubated with anti-OB-R antibody (diluted 1:2,000 in blotto blocking buffer) overnight at $4^{\circ} \mathrm{C}$. OB-R protein expression from muscular extracts was analyzed by Western blot with the preincubation solution. Data are reported as a percentage of OB-R immunostaining values (band quenching) in the presence of increasing amounts of $\mathrm{RH}$ leptin $\mathrm{R} / \mathrm{Fc}$ chimera relative to those observed for a control that was not preincubated with $\mathrm{RH}$ leptin R/Fc.

Potential contamination by whole blood or subcutaneous adipose tissue. To assess if a small contamination by blood could influence the OB-R immunostainings, whole human blood protein extracts were obtained from two healthy subjects and processed for Western blot analysis as described above. Skeletal muscle biopsies may be contaminated by a small amount of adipose tissue, which may come from the adipose tissue accumulated between the muscle bundles and/or by subcutaneous fat tissue. Although the latter possibility was minimized by avoiding the use of suction, the amount of protein material coming from adipose tissue was also assessed in all muscle samples. For this purpose, a protein extract from subcutaneous adipose tissue was first obtained, as reported above. Then, in the same gel, skeletal muscle protein extracts $(50 \mu \mathrm{g})$ were run together with subcutaneous adipose tissue protein extract samples containing 1,2,3,4, or $5 \mu \mathrm{g}$ of protein (Fig. 1A). Then Western blots were performed using a polyclonal rabbit anti-perilipin A antibody as described above. From the band densities obtained for perilipin, a standard curve was calculated by linear regression (all curves had a $r^{2}$ value $\geq 0.98$ ) (Fig. $1 B$ ). The corresponding equation was used to calculate the maximal amount of fat that could be present in each muscle biopsy, assuming that skeletal muscle fibers have undetectable amounts of perilipin A $(26,47)$. To 

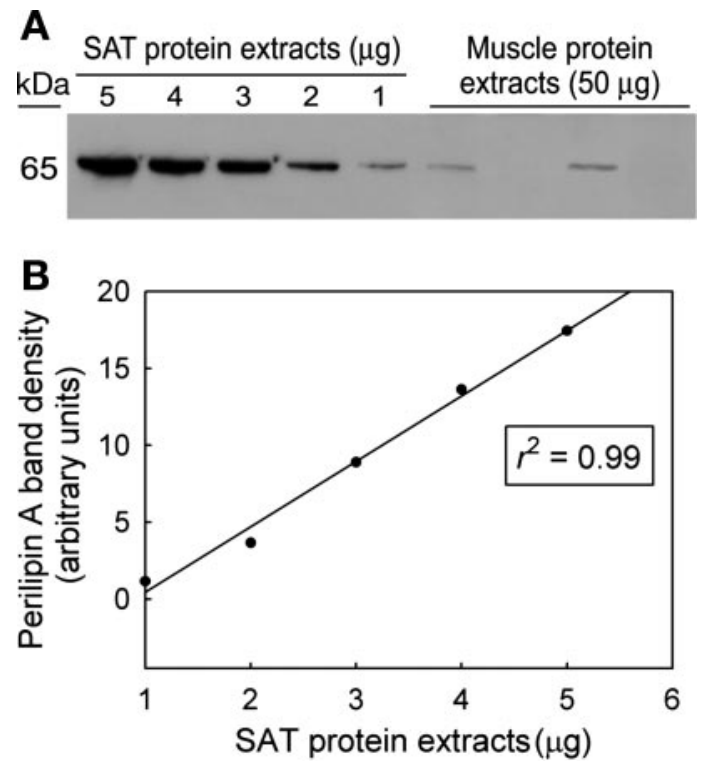

Fig. 1. Determination of perilipin A content to assess the degree of adipose tissue infiltration in human skeletal muscle biopsies. Protein extracts were obtained from muscle and subcutaneous adipose tissue (SAT), and perilipin A protein expression was determined by Western blot. A: representative immunoblotting performed in SAT protein extracts containing $1,2,3,4$, and $5 \mu \mathrm{g}$ of protein and in muscle protein extracts $(50 \mu \mathrm{g}) . B$ : representative standard curve calculated by linear regression $\left(r^{2}=0.99\right)$ from the band densities obtained for perilipin A (arbitrary units).

calculate the potential contribution of some adipose tissue (or adipocytes) present in the muscle samples on the OB-R protein expression, we carried out two additional experiments. First, we added increasing amounts of protein extracts from adipose tissue $(1,2$, and $4 \mu \mathrm{g})$ to 50 $\mu \mathrm{g}$ of muscle protein extract. In the second experiment, increasing amounts of muscle protein extracts were added to $10 \mu \mathrm{g}$ of protein extract from adipose tissue. In both experiments, the expression of OB-R was determined by Western blot analysis.

Leptin assays. Serum leptin was determined by ELISA (ELx800 Universal Microplate Reader, Bioteck Instruments), using reagent kits from Diagnostic Systems Laboratories (Webster, TX) and following the manufacturer's instructions. The sensitivity of the total leptin assays was $0.05 \mathrm{ng} / \mathrm{ml}$ (4). The intra-assay coefficient of variation was $3.8 \%$, and the interassay coefficient of variation was $4.4 \%$.

Statistical analyses. The statistical analyses was performed using the SPSS software package (SPSS, Chicago, IL), version 8.0. All data are reported as means \pm SE. The relationships between leptin and band densities were tested with linear regression analysis. Calibration curves for the relationship between perilipin A band density and protein content from subcutaneous adipose tissue fat were obtained by linear regression analysis. Pearson's correlation coefficients were used to assess associations between leptin and OB-R protein expression. The sample population was ordered according to the basal leptin concentration values and then split into two groups, each composed of seven subjects. One group consisted of the subjects with the seven lowest values of plasma leptin, whereas the other group contained the subjects with the seven highest leptin concentrations. The band densities of the $170-\mathrm{kDa}$ isoform were compared between these two groups using Student's $t$-test. A statistical test was considered significant at $P \leq 0.05$ level (two-tailed).

\section{RESULTS}

Identification of $O B-R$ in human skeletal muscle. The protein expression of the OB-R in human skeletal muscle was determined by Western blot analysis using an antibody raised against its extracellular domain. This antibody revealed the presence of three bands in which molecular mass was $\sim 170$, 128, and $98 \mathrm{kDa}$ (Fig. 2, $A$ and $D$ ). The 170-kDa band was detected in skeletal muscle and hypothalamus protein extracts (Fig. 2A). The other two bands migrating at 128 and $98 \mathrm{kDa}$ were identified in skeletal muscle and thigh subcutaneous adipose tissue protein extracts (Fig. 2A). The 98-kDa band was also found in hypothalamus protein extracts (Fig. 2A). No immunosignal was observed in the absence of primary antibody (data not shown). The $128-\mathrm{kDa}$ isoform was not detected in four subjects, implying that the level of expression was undetectable or that the $128-\mathrm{kDa}$ isoform was not expressed at all in the skeletal muscle (Fig. 2A). In the latter case, the $128-\mathrm{kDa}$ observed in some subjects indicated contamination by surrounding adipose tissue or adipocytes located in between the muscle fibers. In contrast, the $170-$ and the $98-\mathrm{kDa}$ isoforms were detected in all 14 subjects (Fig. 2A).

The densities of the $98-\mathrm{kDa}$ and the $128-\mathrm{kDa}$ OB-R bands ( $r=0.76, P<0.01$ ) and the $170-\mathrm{kDa}$ and the $98-\mathrm{kDa}$ OB-R bands $(r=0.74, P<0.01)$ were correlated. No relationship
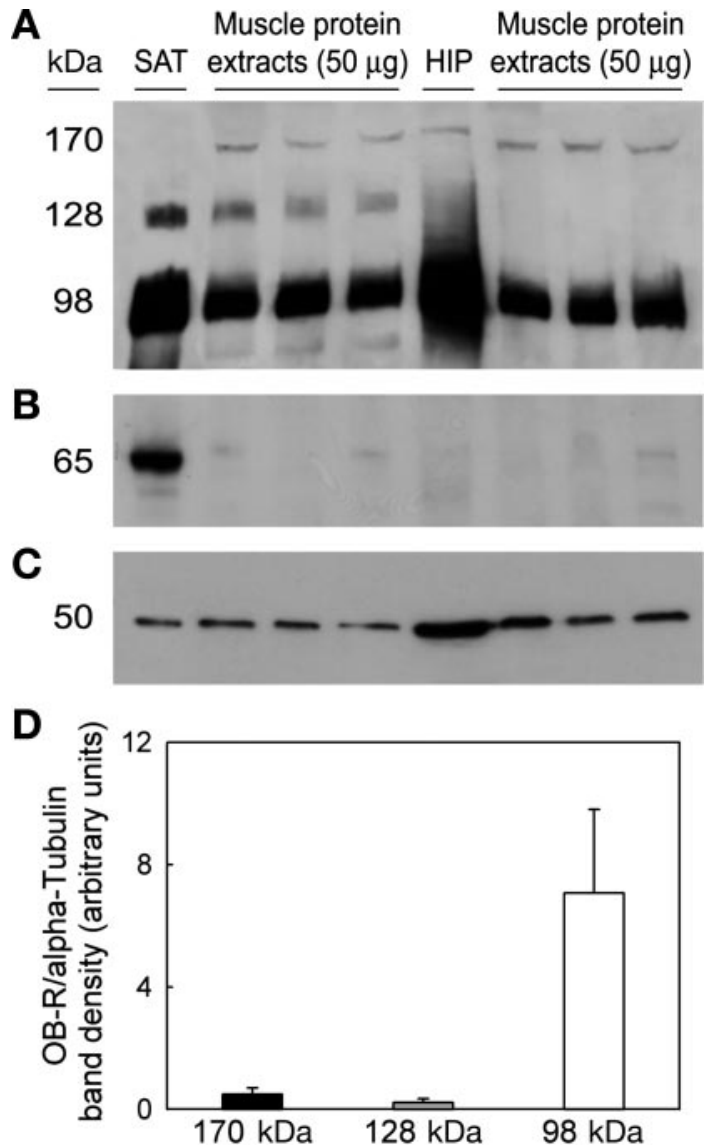

Fig. 2. Determination of the expression of human leptin receptor (OB-R) in human skeletal muscle. Protein extracts were prepared from muscle, SAT, and hypothalamus (HIP), and OB-R, perilipin A, and $\alpha$-tubulin protein expression was analyzed by Western blot. A: representative immunoblot assay after incubation with a polyclonal rabbit anti-OB-R antibody specifically raised against the long isoform. $B$ : representative Western blot after incubation with a polyclonal rabbit anti-perilipin A antibody in the same samples used in $A$. $C$ : representative immunoblot analysis after incubation with the monoclonal mouse anti- $\alpha$-tubulin antibody in the same samples used in $A$. $D$ : densitometric immunosignal values (arbitrary units of band densities) of OB-R bands relative to those obtained for $\alpha$-tubulin. 
was observed between the densities of the 170-kDa and 128$\mathrm{kDa}$ OB-R bands.

Specificity of the antibody: competitive assays. Competitive assays with $\mathrm{RH}$ leptin $\mathrm{R} / \mathrm{Fc}$ chimera as a competitive blocker of the antigen-antibody interaction showed that the antibody was able to bind specifically to the three bands detected (Fig. 3). This implies that the OB-R bands share a common epitope with the RH leptin $\mathrm{R} / \mathrm{Fc}$ chimera, which contains an amino acid sequence of the extracellular domain of the human OB-R.

Contribution of adipose tissue to the $O B-R$ band density in skeletal muscle tissue. Assuming that muscle fibers do not express perilipin A (47), the band density of perilipin A measured by immunoblotting (Fig. 1) and normalized by $\alpha$-tubulin was equivalent to the presence of $1.18 \pm 0.13 \mu \mathrm{g}$ of protein coming from adipose tissue in $50 \mu \mathrm{g}$ (Fig. $2 B$ ) of protein extract obtained from the muscle biopsies. This perilipin A band density corresponded to a level of contamination by adipose tissue protein of $2.4 \pm 0.2 \%$ in the protein extract from the muscle biopsies. By adding different amounts of protein extracts from subcutaneous adipose tissue to $50 \mu \mathrm{g}$ of muscle protein extract, we obtained by linear regression an equation describing the impact that contamination by adipose tissue had on the muscular 170-, 128-, and 98-kDa band densities (Fig. 4A). With the determination of perilipin A protein content in muscular tissue, we obtained a value of potential contamination by fat that,

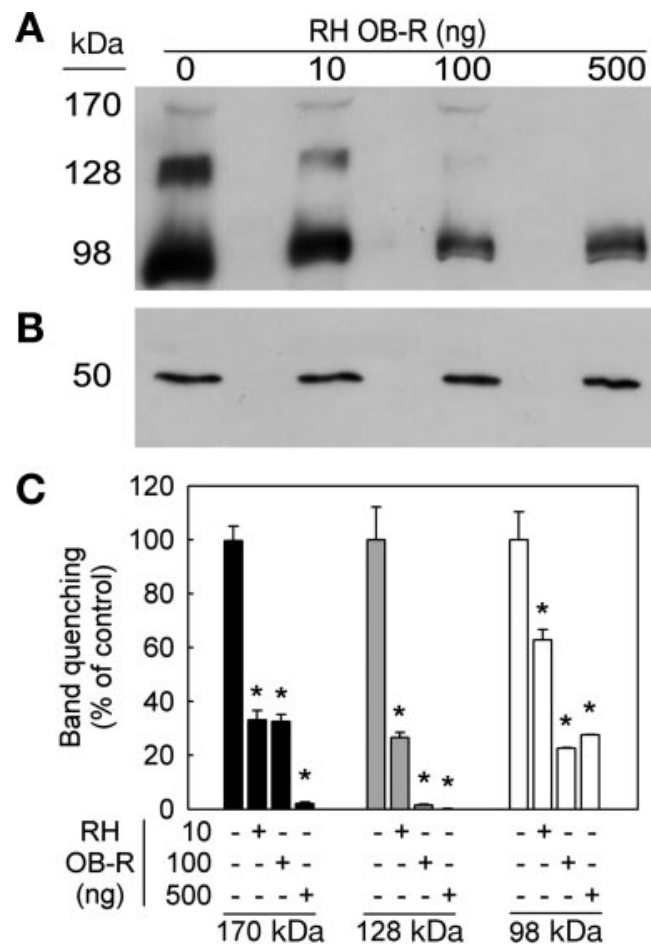

Fig. 3. The anti-OB-R antibody recognized specifically the three OB-R bands detected in the muscle protein extracts. Increasing amounts of recombinant human (RH) leptin R/Fc (RH OB-R) chimera (0, 10, 100, $500 \mathrm{ng}$ ) were preincubated with anti-OB-R antibody $(1: 2,000)$. OB-R protein expression from muscle extracts was analyzed by immunoblotting using the preincubation solution. A: representative Western blot analysis with different preincubation solutions in the same muscle protein extract $(50 \mu \mathrm{g})$. B: representative immunoblot with the $\alpha$-tubulin antibody as a loading control. $C$ : densitometric percentage of OB-R immnunostaining values (band quenching) in presence of increasing amounts $(10,100,500 \mathrm{ng})$ of RH OB-R relative to those observed for a control $(0 \mathrm{ng}$ of RH OB-R). $* P<0.01$ vs. $0 \mathrm{ng}$ of RH OB-R.

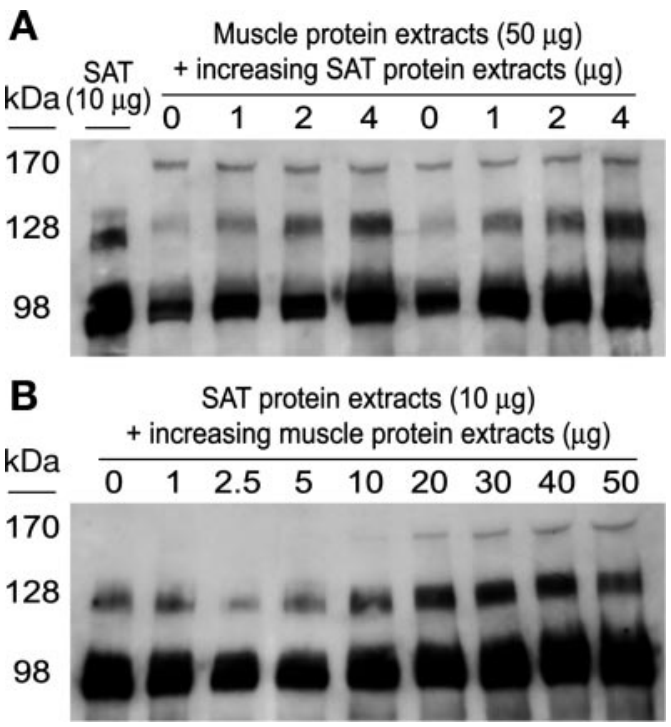

Fig. 4. Assessment of the contribution of different amounts of adipose tissue on the optical density of the three OB-R bands and determination of the minimal amount of muscle protein extract needed to detect the presence of OB-R. Protein extracts were obtained from human muscle and SAT, and OB-R protein expression was determined by Western blot using a polyclonal rabbit anti-OB-R antibody. A: representative immunoblot performed with increasing amounts of protein extracts $(1,2$, and $4 \mu \mathrm{g})$ from SAT added to $50 \mu \mathrm{g}$ of muscle protein extract. $B$ : representative Western blot performed with increasing amounts of muscle protein extracts ( 0 to $50 \mu \mathrm{g}$ ) added to $10 \mu \mathrm{g}$ of protein extract from SAT.

when combined with the previous experiment, allowed us to calculate how much of the specific OB-R band densities could be explained by contamination of the muscle sample with subcutaneous adipose tissue. Contamination by adipose tissue could account for $89 \%$ of the $98-\mathrm{kDa}$ OB-R band density and for all of the $128-\mathrm{kDa}$ band density observed in the muscle protein extract. In turn, the contamination by adipose tissue had no effect on the 170-kDa density (Fig. 4A). Adding increasing amounts of muscle protein extract to $10 \mu \mathrm{g}$ of subcutaneous adipose tissue protein extract resulted in a proportional increase of the three OB-R band densities (Fig. 4B). The 170$\mathrm{kDa}$ band was only detectable when $10 \mu \mathrm{g}$ or more of muscle protein extracts were added to the adipose tissue protein extract (Fig. 4B).

There was no sign of OB-R contamination from blood, since, in protein extracts from whole blood (with loads up to $100 \mu \mathrm{g}$ of protein), OB-R was undetectable (data not shown).

Relationship between serum leptin and muscle $O B-R$ bands. Serum leptin concentration was $15.9 \pm 2.7 \mathrm{ng} / \mathrm{ml}$. There was no relationship between serum leptin concentration and the 170-kDa OB-R band density. There was a trend for a linear relationship between serum leptin and the $98-\mathrm{kDa}$ band density $(r=0.52, P=0.06)$. Despite huge differences in basal leptin concentration in serum between the group with low and high basal leptin concentrations in serum $(7.9 \pm 1.6$ and $23.9 \pm 2.9$ $\mathrm{ng} / \mathrm{ml}$, respectively, $P<0.05$ ), the $170-\mathrm{kDa}$ OB-R optical density was similar $(0.51 \pm 0.10$ and $0.47 \pm 0.05$ arbitrary units, respectively, $P=0.74$ ).

\section{DISCUSSION}

In the present study, we hypothesized that the OB-R protein should be expressed in human skeletal muscle. This was based 
on previous studies revealing the presence of OB-R mRNA in human skeletal muscle (17) and cultures of primary skeletal muscle cells (55), and also on the fact that primary skeletal muscle cells in culture respond to leptin by increasing ERK activity (55) and/or AMP-activated protein kinase activity and fatty acid oxidation $(41,59)$. This study confirms this hypothesis and describes a Western blot-based procedure to assess OB-R protein. This immunoblotting analysis was carried out using a polyclonal rabbit anti-human OB-R antibody in protein extracts obtained from muscle biopsies and revealed the presence of a dense band with a molecular mass close to $98 \mathrm{kDa}$ and another two less intense bands, with molecular masses of 128 and $170 \mathrm{kDa}$. The 128 and $98 \mathrm{kDa}$ bands were in agreement with the molecular mass of the short and long isoforms of OB-R (OB-Ra and OB-Rb, respectively), detected in other human tissues including brain, liver, digestive tract, umbilical cord, and fetal membranes $(2,3,14,22,39)$. Furthermore, the $170-\mathrm{kDa}$ band was compatible with the molecular mass observed for $\mathrm{OB}-\mathrm{Rb}$ in human umbilical venous endothelial cells (13). Our results also demonstrate that the density of these three bands was reduced in competitive Western blot assays performed with increasing concentrations of $\mathrm{RH}$ leptin $\mathrm{R} / \mathrm{Fc}$ chimera, which contains the extracellular domain (aa residues 1-839) of OB-R. These data suggest that the antibody used in this study recognized specifically the three OB-R bands detected in skeletal muscle and that muscular tissue OB-R proteins detected with this antibody contain the extracellular domain of the human OB-R.

These results implied that human skeletal muscle expresses the long and short isoforms of the leptin receptor. However, skeletal muscle is a complex tissue, and some adipose tissue (or adipocytes) may be present in between or around the muscle fibers and/or bundles $(25,29)$. Only the intermuscular adipose tissue (IMAT) that was visible could be removed during the manipulation of the muscle biopsies. This means that, in any muscle biopsy, there is always the potential for contamination by IMAT, which may be irrelevant for many purposes, but critical in this study. Whole body IMAT has been measured using multislice MRI $(25,29)$. The IMAT compartment includes IMAT that is located between muscle groups and beneath the muscle fascia and IMAT that is distributed within individual muscles visible on MRI images. IMAT mean values of $1.7,2.2$, and $2.5 \%$ have been reported in men having a mean percentage of body fat of $10.8,25.3$, and $20.2 \%$, respectively $(25,29)$. Using a different approach that allows a physical separation of adipocytes from the muscle fibers in surgical muscle biopsies, Mingrone et al. (40) reported that intermuscular triglycerides represented 3.1 and $15.9 \%$ of the muscle mass in lean and obese subjects, respectively, which is equivalent to $4-20 \%$ in mass of adipose tissue, assuming that triglycerides represent $\sim 80 \%$ of the adipocyte composition. In the present investigation, we observed that $2.4 \%$ of the proteins extracted from the muscle biopsies were from IMAT. This implies that IMAT mass in our muscle biopsies should have attained a higher value, which could only have been ascertained by knowing the protein composition of the muscle and adipose tissue in this location. However, the important point to bear in mind is that even a "clean" skeletal muscle biopsy always contains a significant amount of adipose tissue, a fact that has been often overlooked in other studies examining the expression of OB-R mRNA $(17,34,48)$.
Solberg et al. (55) reported the existence of a functional long isoform of the OB-R in primary skeletal muscle cells derived from human skeletal muscle biopsies. To obtain these cells, the authors first separated the satellite cells by dissection and successive incubations with trypsin/EDTA. Then the satellite cells were grown in culture wells where they differentiated into myoblasts and fused together, leading to the formation of myotubes. When these myotubes were exposed to leptin, they responded by ERK activation, with a small increase in fatty acid oxidation. A similar stimulation of fat oxidation by leptin has also been reported in cultured myotubes derived from lean but not obese humans (59). However, it should be considered that myotubes may express different proteins from adult muscle fibers in vivo and that, during the process of in vitro differentiation, some satellite cells could have differentiated into adipocytes (52). Using an isolated rectus abdominis muscle preparation from lean and obese humans, Steinberg et al. (60) observed that leptin promotes fat oxidation only in lean subjects, when stimulated at high nonphysiological leptin concentrations (in the absence of insulin and other hormonal factors). Although these findings indirectly suggest the presence of a functional leptin receptor in human skeletal muscle, this in vitro preparation would likely contain a considerable amount of IMAT and other cell types, which could account differentially for the effects reported in fat oxidation.

The present investigation clearly shows that the 170-kDa OB-R isoform is only present in the muscle fibers and is not detectable in adipose tissue. However, both the 98- and 128$\mathrm{kDa}$ bands could originate from the IMAT. This is further demonstrated by the fact that loading the gels with increasing amounts of protein extracts from subcutaneous adipose tissue increased the staining intensity corresponding to the 98- and $128-\mathrm{kDa}$ bands, without any effect on the $170-\mathrm{kDa}$ band. Knowing the amount of protein from adipose tissue present in each biopsy and the amount of 98- and 128-kDa OB-R density present in the subcutaneous adipose tissue, we have calculated that IMAT is able to explain all of the $128-\mathrm{kDa}$ OB-R band density and $89 \%$ of the $98-\mathrm{kDa}$ OB-R band density. The lack of antibodies specific for the 170- and $98-\mathrm{kDa}$ isoforms impedes our ability, using immunohistochemical techniques, to resolve whether the $98 \mathrm{kDa}$ is really present at the protein level in the muscle fibers.

Although a circulating form of the leptin receptor (OB-Re) lacking the transmembrane and intracellular domains (24) may contaminate the skeletal muscle samples, this isoform was not recognized by the anti-OB-R antibody used in this investigation, since Western blot analysis loading up to $100 \mu \mathrm{g}$ of protein extract from blood leucocyte fraction was negative for OB-R (data not shown). This is likely due to structural and/or compositional differences between the extracellular domain of the OB-Re and that of the OB-Ra, OB-Rb, and OB-Rf isoforms (1). Thus we can rule out contamination by blood as source of OB-R immunoreactivity in our muscle samples.

The presence of a long isoform of the leptin receptor in the skeletal muscle fibers might have important implications for the understanding of the metabolic regulation of human energy metabolism and may be critical to unravel the physiopathology of the metabolic syndrome and insulin resistance $(57,59)$. The $170-\mathrm{kDa}$ band could very well be the main ligand for leptin in skeletal muscle $(9,11,12,61)$. It has also been shown that this isoform phosphorylates in response to leptin binding (8), and 
this phosphorylation has been linked to the activation of intracellular cascades with subsequent effects on fatty acid transport and metabolism $(41,42,58)$.

In summary, this study shows that a long isoform of the leptin receptor with a molecular mass close to $170 \mathrm{kDa}$ is expressed at the protein level in human skeletal muscle. The amount of $170-\mathrm{kDa}$ protein appears to be independent of the basal concentration of leptin in serum. In addition, we describe a procedure based on the determination of perilipin A content, a protein exclusive of adipocytes, to determine the degree of adipose tissue infiltration in human muscle biopsies. The latter procedure was critical for the interpretation of our results. Adipose tissue contamination must be assessed when using rough protein extracts from skeletal muscle, if the aim is to study molecules that may also be present in IMAT. Future experiments with human and animal models of hypo- and hyperleptinemia, and longitudinal studies in dieting and/or exercising humans, should be carried out to establish the role of this isoform of the leptin receptor in the regulation of skeletal muscle metabolism.

\section{ACKNOWLEDGMENTS}

The authors thank Dr. Andrew S. Greenberg for kindly providing the anti-perilipin A antibody. Special thanks are given to José Navarro de Tuero for excellent technical assistance and to Ana Navarro y Guerra del Río for attendance in the elaboration of immunoblotting figures. The specialized advice from Tony Webster in editing the English version of the manuscript is also acknowledged. Special thanks are given to all subjects who volunteered for these experiments. We express our gratitude to Gundela Meyer for help with the human hypothalamus.

\section{GRANTS}

This study was supported by grants from the Ministerio de Educación y Ciencia (BFI2003-09638, BFU2006-13784, and FEDER) and the Gobierno de Canarias (PI2005/177). We are grateful for all the support provided by the Academia Canaria de Seguridad and particularly to Juan Manuel Castañeda Contreras. B. Guerra is a fellow of the "Recursos Humanos y Difusión de la Investigación" Programe (Instituto de Salud Carlos III, Ministerio de Sanidad y Consumo, Spain).

\section{REFERENCES}

1. Ahima RS, Flier JS. Leptin. Annu Rev Physiol 62: 413-437, 2000.

2. Akerman F, Lei ZM, Rao CV. Human umbilical cord and fetal membranes co-express leptin and its receptor genes. Gynecol Endocrinol 16: 299-306, 2002.

3. Aparicio T, Kermorgant S, Darmoul D, Guilmeau S, Hormi K, Mahieu-Caputo $\mathbf{D}$, Lehy $\mathbf{T}$. Leptin and $\mathrm{Ob}-\mathrm{Rb}$ receptor isoform in the human digestive tract during fetal development. J Clin Endocrinol Metab 90: 6177-6184, 2005

4. Ara I, Pérez Gómez J, Vicente-Rodriguez G, Chavarren J, Dorado C, Calbet JA. Serum free testosterone, leptin and soluble leptin receptor changes in a 6-week strength-training programme. Br J Nutr 96: 10531059, 2006.

5. Ara I, Vicente-Rodriguez G, Jimenez-Ramirez J, Dorado C, SerranoSanchez JA, Calbet JA. Regular participation in sports is associated with enhanced physical fitness and lower fat mass in prepubertal boys. Int $J$ Obes Relat Metab Disord 28: 1585-1593, 2004.

6. Ara I, Vicente-Rodriguez G, Perez-Gomez J, Jimenez-Ramirez J, Serrano-Sanchez JA, Dorado C, Calbet JA. Influence of extracurricular sport activities on body composition and physical fitness in boys: a 3-year longitudinal study. Int J Obes 30: 1062-1071, 2006.

7. Argiles JM, Lopez-Soriano J, Almendro V, Busquets S, LopezSoriano FJ. Cross-talk between skeletal muscle and adipose tissue: a link with obesity? Med Res Rev 25: 49-65, 2005.

8. Bates SH, Myers MG Jr. The role of leptin receptor signaling in feeding and neuroendocrine function. Trends Endocrinol Metab 14: 447-452, 2003.
9. Baumann H, Morella KK, White DW, Dembski M, Bailon PS, Kim H, Lai CF, Tartaglia LA. The full-length leptin receptor has signaling capabilities of interleukin 6-type cytokine receptors. Proc Natl Acad Sci USA 93: 8374-8378, 1996.

10. Bjorbaek C, Kahn BB. Leptin signaling in the central nervous system and the periphery. Recent Prog Horm Res 59: 305-331, 2004.

11. Bjorbaek C, Lavery HJ, Bates SH, Olson RK, Davis SM, Flier JS, Myers MG Jr. SOCS3 mediates feedback inhibition of the leptin receptor via Tyr985. J Biol Chem 275: 40649-40657, 2000.

12. Bjorbaek C, Uotani S, da Silva B, Flier JS. Divergent signaling capacities of the long and short isoforms of the leptin receptor. J Biol Chem 272: 32686-32695, 1997.

13. Bouloumie A, Drexler HC, Lafontan M, Busse R. Leptin, the product of Ob gene, promotes angiogenesis. Circ Res 83: 1059-1066, 1998.

14. Briscoe CP, Hanif S, Arch JR, Tadayyon M. Leptin receptor long-form signalling in a human liver cell line. Cytokine 14: 225-229, 2001.

15. Burguera B, Couce ME, Long J, Lamsam J, Laakso K, Jensen MD, Parisi JE, Lloyd RV. The long form of the leptin receptor $(\mathrm{OB}-\mathrm{Rb})$ is widely expressed in the human brain. Neuroendocrinology 71: 187-195, 2000.

16. Cabrera-Socorro A, Pueyo Morlans M, Suarez Sola ML, Gonzalez Delgado FJ, Castaneyra-Perdomo A, Marin MC, Meyer G. Multiple isoforms of the tumor protein p73 are expressed in the adult human telencephalon and choroid plexus and present in the cerebrospinal fluid. Eur J Neurosci 23: 2109-2118, 2006.

17. Ceddia RB, William WN Jr, Curi R. The response of skeletal muscle to leptin. Front Biosci 6: D90-D97, 2001.

18. Chua SC Jr, Koutras IK, Han L, Liu SM, Kay J, Young SJ, Chung WK, Leibel RL. Fine structure of the murine leptin receptor gene: splice site suppression is required to form two alternatively spliced transcripts. Genomics 45: 264-270, 1997.

19. Considine RV, Caro JF. Leptin and the regulation of body weight. Int J Biochem Cell Biol 29: 1255-1272, 1997.

20. Considine RV, Sinha MK, Heiman ML, Kriauciunas A, Stephens TW, Nyce MR, Ohannesian JP, Marco CC, McKee LJ, Bauer TL, Caro JF. Serum immunoreactive-leptin concentrations in normal-weight and obese humans. N Engl J Med 334: 292-295, 1996.

21. Cornish J, Callon KE, Bava U, Lin C, Naot D, Hill BL, Grey AB, Broom N, Myers DE, Nicholson GC, Reid IR. Leptin directly regulates bone cell function in vitro and reduces bone fragility in vivo. $J$ Endocrinol 175: 405-415, 2002.

22. Couce ME, Burguera B, Parisi JE, Jensen MD, Lloyd RV. Localization of leptin receptor in the human brain. Neuroendocrinology 66: 145-150, 1997.

23. Dulloo AG, Stock MJ, Solinas G, Boss O, Montani JP, Seydoux J. Leptin directly stimulates thermogenesis in skeletal muscle. FEBS Lett 515: 109-113, 2002.

24. Friedman JM, Halaas JL. Leptin and the regulation of body weight in mammals. Nature 395: 763-770, 1998.

25. Gallagher D, Kuznia P, Heshka S, Albu J, Heymsfield SB, Goodpaster B, Visser M, Harris TB. Adipose tissue in muscle: a novel depot similar in size to visceral adipose tissue. Am J Clin Nutr 81: 903-910, 2005.

26. Greenberg AS, Egan JJ, Wek SA, Garty NB, Blanchette-Mackie EJ, Londos C. Perilipin, a major hormonally regulated adipocyte-specific phosphoprotein associated with the periphery of lipid storage droplets. J Biol Chem 266: 11341-11346, 1991.

27. Hekerman P, Zeidler J, Bamberg-Lemper S, Knobelspies H, Lavens D, Tavernier J, Joost HG, Becker W. Pleiotropy of leptin receptor signalling is defined by distinct roles of the intracellular tyrosines. FEBS J 272: 109-119, 2005.

28. Houmard JA, Cox JH, MacLean PS, Barakat HA. Effect of short-term exercise training on leptin and insulin action. Metabolism 49: 858-861, 2000.

29. Kim J, Heshka S, Gallagher D, Kotler DP, Mayer L, Albu J, Shen W, Freda PU, Heymsfield SB. Intermuscular adipose tissue-free skeletal muscle mass: estimation by dual-energy X-ray absorptiometry in adults. J Appl Physiol 97: 655-660, 2004.

30. Krentz AJ. Insulin resistance. BMJ 313: 1385-1389, 1996.

31. Laemmli UK. Cleavage of structural proteins during the assembly of the head of bacteriophage T4. Nature 227: 680-685, 1970.

32. Lee DW, Leinung MC, Rozhavskaya-Arena M, Grasso P. Leptin and the treatment of obesity: its current status. Eur J Pharmacol 440: 129 139, 2002. 
33. Lee GH, Proenca R, Montez JM, Carroll KM, Darvishzadeh JG, Lee JI, Friedman JM. Abnormal splicing of the leptin receptor in diabetic mice. Nature 379: 632-635, 1996.

34. Liu YL, Emilsson V, Cawthorne MA. Leptin inhibits glycogen synthesis in the isolated soleus muscle of obese (ob/ob) mice. FEBS Lett 411: 351-355, 1997.

35. Lundby C, Sander M, van Hall G, Saltin B, Calbet JA. Maximal exercise and muscle oxygen extraction in acclimatizing lowlanders and high altitude natives. J Physiol 573: 535-547, 2006.

36. Margetic S, Gazzola C, Pegg GG, Hill RA. Leptin: a review of its peripheral actions and interactions. Int J Obes Relat Metab Disord 26: 1407-1433, 2002.

37. Maroni P, Bendinelli P, Piccoletti R. Early intracellular events induced by in vivo leptin treatment in mouse skeletal muscle. Mol Cell Endocrinol 201: 109-121, 2003.

38. Mars M, de Graaf C, de Groot CP, van Rossum CT, Kok FJ. Fasting leptin and appetite responses induced by a 4-day 65\%-energy-restricted diet. Int J Obes 30: 122-128, 2006.

39. Merino B, Diez-Fernandez C, Ruiz-Gayo M, Somoza B. Choroid plexus epithelial cells co-express the long and short form of the leptin receptor. Neurosci Lett 393: 269-272, 2006.

40. Mingrone G, Bertuzzi A, Capristo E, Greco AV, Manco M, Pietrobelli A, Salinari S, Heymsfield SB. Unreliable use of standard muscle hydration value in obesity. Am J Physiol Endocrinol Metab 280: E365-E371, 2001.

41. Minokoshi Y, Kim YB, Peroni OD, Fryer LG, Muller C, Carling D, Kahn BB. Leptin stimulates fatty-acid oxidation by activating AMPactivated protein kinase. Nature 415: 339-343, 2002.

42. Muoio DM, Dohm GL, Fiedorek FT Jr, Tapscott EB, Coleman RA. Leptin directly alters lipid partitioning in skeletal muscle. Diabetes 46: 1360-1363, 1997.

43. Muoio DM, Lynis Dohm G. Peripheral metabolic actions of leptin. Best Pract Res Clin Endocrinol Metab 16: 653-666, 2002.

44. Olefsky JM, Kolterman OG, Scarlett JA. Insulin action and resistance in obesity and noninsulin-dependent type II diabetes mellitus. Am J Physiol Endocrinol Metab 243: E15-E30, 1982.

45. Pelleymounter MA, Cullen MJ, Baker MB, Hecht R, Winters D, Boone T, Collins F. Effects of the obese gene product on body weight regulation in ob/ob mice. Science 269: 540-543, 1995.

46. Perusse L, Collier G, Gagnon J, Leon AS, Rao DC, Skinner JS, Wilmore JH, Nadeau A, Zimmet PZ, Bouchard C. Acute and chronic effects of exercise on leptin levels in humans. J Appl Physiol 83: 5-10, 1997.

47. Phillips SA, Choe CC, Ciaraldi TP, Greenberg AS, Kong AP, Baxi SC, Christiansen L, Mudaliar SR, Henry RR. Adipocyte differentiationrelated protein in human skeletal muscle: relationship to insulin sensitivity. Obes Res 13: 1321-1329, 2005.

48. Ramsay TG, Richards MP. Leptin and leptin receptor expression in skeletal muscle and adipose tissue in response to in vivo porcine somatotropin treatment. J Anim Sci 83: 2501-2508, 2005.

49. Sahu A. Leptin signaling in the hypothalamus: emphasis on energy homeostasis and leptin resistance. Front Neuroendocrinol 24: 225-253, 2003.
50. Segal KR, Landt M, Klein S. Relationship between insulin sensitivity and plasma leptin concentration in lean and obese men. Diabetes 45: 988-991, 1996.

51. Seron K, Corset L, Vasseur F, Boutin P, Gomez-Ambrosi J, Salvador J, Fruhbeck G, Froguel P. Distinct impaired regulation of SOCS3 and long and short isoforms of the leptin receptor in visceral and subcutaneous fat of lean and obese women. Biochem Biophys Res Commun 348: 1232-1238, 2006.

52. Shefer G, Wleklinski-Lee M, Yablonka-Reuveni Z. Skeletal muscle satellite cells can spontaneously enter an alternative mesenchymal pathway. J Cell Sci 117: 5393-5404, 2004.

53. Shih CD, Au LC, Chan JY. Differential role of leptin receptors at the hypothalamic paraventricular nucleus in tonic regulation of food intake and cardiovascular functions. J Biomed Sci 10: 367-378, 2003.

54. Smith PK, Krohn RI, Hermanson GT, Mallia AK, Gartner FH, Provenzano MD, Fujimoto EK, Goeke NM, Olson BJ, Klenk DC. Measurement of protein using bicinchoninic acid. Anal Biochem 150: 76-85, 1985.

55. Solberg R, Aas V, Thoresen GH, Kase ET, Drevon CA, Rustan AC, Reseland JE. Leptin expression in human primary skeletal muscle cells is reduced during differentiation. J Cell Biochem 96: 89-96, 2005.

56. Sorensen TI, Echwald S, Holm JC. Leptin in obesity. BMJ 313: 953-954, 1996.

57. Steinberg GR, Dyck DJ. Development of leptin resistance in rat soleus muscle in response to high-fat diets. Am J Physiol Endocrinol Metab 279: E1374-E1382, 2000.

58. Steinberg GR, Dyck DJ, Calles-Escandon J, Tandon NN, Luiken JJ, Glatz JF, Bonen A. Chronic leptin administration decreases fatty acid uptake and fatty acid transporters in rat skeletal muscle. J Biol Chem 277: 8854-8860, 2002.

59. Steinberg GR, McAinch AJ, Chen MB, O'Brien PE, Dixon JB, Cameron-Smith D, Kemp BE. The suppressor of cytokine signaling 3 inhibits leptin activation of AMP-kinase in cultured skeletal muscle of obese humans. J Clin Endocrinol Metab 91: 3592-3597, 2006.

60. Steinberg GR, Parolin ML, Heigenhauser GJ, Dyck DJ. Leptin increases FA oxidation in lean but not obese human skeletal muscle: evidence of peripheral leptin resistance. Am J Physiol Endocrinol Metab 283: E187-E192, 2002.

61. Tartaglia LA. The leptin receptor. J Biol Chem 272: 6093-6096, 1997.

62. Thong FS, Hudson R, Ross R, Janssen I, Graham TE. Plasma leptin in moderately obese men: independent effects of weight loss and aerobic exercise. Am J Physiol Endocrinol Metab 279: E307-E313, 2000.

63. Towbin H, Staehelin T, Gordon J. Electrophoretic transfer of proteins from polyacrylamide gels to nitrocellulose sheets: procedure and some applications. Proc Natl Acad Sci USA 76: 4350-4354, 1979.

64. Wang Y, Sullivan S, Trujillo M, Lee MJ, Schneider SH, Brolin RE, Kang YH, Werber Y, Greenberg AS, Fried SK. Perilipin expression in human adipose tissues: effects of severe obesity, gender, and depot. Obes Res 11: 930-936, 2003.

65. White DW, Tartaglia LA. Leptin and OB-R: body weight regulation by a cytokine receptor. Cytokine Growth Factor Rev 7: 303-309, 1996.

66. Zhang F, Basinski MB, Beals JM, Briggs SL, Churgay LM, Clawson DK, DiMarchi RD, Furman TC, Hale JE, Hsiung HM, Schoner BE, Smith DP, Zhang XY, Wery JP, Schevitz RW. Crystal structure of the obese protein leptin-E100. Nature 387: 206-209, 1997. 